УДК 78.071.2(477)

DOI:

Ірина Кліш, доцент кафедри народних музичних інструментів та вокалу Дрогобицького державного педагогічного університету імені Івана Франка

\title{
МИСТЕЦЬКА ДІЯЛЬНІСТЬ МАРІЇ ЛИТВИНЕНКО-ВОЛЬГЕМУТ В КОНТЕКСТІ РОЗВИТКУ УКРАЇНСЬКОЇ МУЗИЧНОЇ КУЛЬТУРИ
}

У статті розкривається творчий портрет співачки, твория украӥнського музичного мистецтвва, педагога, театральної й громадської діячки Марії Литвиненко-Вольгемут на тлі розвитку украӥнського музичного мистецтва.

Ім'я видатної співачки, народної артистки України Марії Литвиненко-Вольгемут (1892 - 1966), тісно пов 'язане з иүілою епохою розвитку української національної культури та становлення національного оперного театру. Вона володіла чудовим і могутнім лірико-драматичним сопрано, иирокого діапазону з прекрасним тембральним забарвленням, а також бездоганною інтоначією, прекрасним диханням, неповторною теплотою $i$ задушевністю виконання. Всі иј якості вповні дозволяли їй розширювати $і$ збагачувати оперний та концертний репертуар.Вокально-виконавські традиції видатної української співачки і сьогодні живуть у творчості талановитих майстрів оперного мистецтва. Ї̈ творчість завжди буде невичерпним джерелом натхнення для подальиих поколінь.

Ключові слова: Марія Литвиненко-Вольгемут; співачка; лірико-драматичне сопрано; опера; тембр дихання; педагогічна діяльність.

תim. 8.

Iryna Klish, Associate Professor of the Folk Musical Instruments and Vocal Singing Department Drohobych Ivan Franko State Pedagogical University

\section{MARIYALYTVYNENKO-WOHLGEMUTH'S ARTISTIC ACTIVITIES IN THE CONTEXT OF THE DEVELOPMENT OFTHE UKRAINIAN MUSICAL CULTURE}

The article reveals the creative image of a singer, a creative representative of Ukrainian musical art, an educator, a theatrical and civic activist, Mariya Lytvynenko-Wohlgemuth, viewed against the background and in the context of the development of Ukrainian musical art.

The name of the prominent singer and People's Artist of Ukraine Mariya Lytvynenko-Wohlgemuth (1892 1966), is closely related to an entire era of development of Ukrainian national culture and the rise of Ukrainian national opera art. She commanded a miraculous and powerful lyrical and dramatical soprano voice with a wide range and a superb timbral colouration as well as a perfect intonation, formidable breathing, and was marked by incredible warmth and cordiality in her performance. All of these qualities have allowed her to expand and enrich the opera and concert repertoire in full. Throughout her stage career, she performed over 80 leading parts in Ukrainian, Western European, and Russian operas, created bright and unforgettable images that have become the school of mastery for many generations of Ukrainian performers.

She was one of the few opera singers who, until her last days, retained the beauty, the freshness and the charm of her voice, the impeccable intonation and excellent command of sound. All of the above testified to the correct voice placement and voice utilisation throughout the forty years of her creative path.

Mariya Lytvynenko-Wohlgemuth dedicated over thirty years of her career to her work as an educator, being employed at the capital's conservatory. As she was transferring her own experience and her own art concepts to her students, she was every time rethinking her creative path and the principles that had been discovered by her intuitively, and that had been building up into a system of certain methodological rules, wherein they became invested with certain theoretical generalisations.

Vocal and performance traditions pertaining to the prominent Ukrainian singer keep living in the creative works of talented maestros of the opera art even today. Her creative heritage will always be an inexhaustible source of inspiration for the future generations.

Keywords: Mariya Lytvynenko-Volgemut; a singer; a lyric-dramatic soprano; opera timbre; breath; pedagogical activity.

П остановка проблеми. Ім'я видатної співачки, народної артистки України Марії Литвиненко-Вольгемут, тісно пов'язане з цілою епохою розвитку української національної культури та становлення національного оперного театру. Вона володіла чудовим і могутнім лірико-драматичним сопрано, широкого діапазону з прекрасним тембральним забарвленням, а також бездоганною інтонацією, прекрасним диханням, неповторною теплотою і 


\section{МИСТЕЦЬКАДІЯЛЬНІСТЬМАРІЇ ЛИТВИНЕНКО-ВОЛЬГЕМУТ В КОНТЕКСТІ РОЗВИТКУ УКРАЇНСЬКОӤ МУЗИЧНОЇ КУЛЬТУРИ}

задушевністю виконання. Всі ці якості вповні дозволяли їй розширювати і збагачувати оперний та концертний репертуар.

За час своєї сценічної діяльності вона виконала понад 80 провідних партій в українських, західноєвропейських та російських операх, створила яскраві і незабутні образи, які стали школою майстерності багатьох поколінь українських виконавців.

Аналіз основних досліджень та публікацій. Творчість Марії Литвиненко-Вольгемут викликала зацікавлення іiї сучасників, які залишили чудові спогади про співачку: А. Рудницький, В. Тольба, М. Голинський, М. Гришко, В. Гужова, Н. Скоробагатько, Т. Швачко, С. Козак. І сьогодні до її мистецької діяльності звертаються мистецтвознавці І. Лисенко, Т. Кроп, О. Ізваріна, В. Харитонова.

Мета статті полягає в розкритті творчого портретуспівачки, творця українського музичного мистецтва, педагога, театральної й громадської діячки Марії Литвиненко-Вольгемут на тлі розвитку українського музичного мистецтва.

Виклад основного матеріалу. "Голос Марії Литвиненко-Вольгемут належав до рідких “рівних" в цілому діапазоні, з солідними, повними низами, металічно-звучними верхами, які навіть на високому “С” ніколи не були різкі, але завжди м'яко заокруглені. Своєрідний тембр надавав голосові окремий своєрідний чар. Музикальність цієї співачки й її певність знання партій були загально відомі диригентам і їі товаришампартнерам. Бувши дуже короткозора ЛитвиненкоВольгемут не могла добре бачити диригента та його рухів, але не дивлячись на те, вона була на сцені одною з найбільш певних і “надійних" оперних співачок” $[4,271]$.

Марія Литвиненко-Вольгемут ( 3 дому Литвиненко) народилася 13 лютого 1892 року в Києві у великій співочій родині - батько мав прекрасний бас, чудово співала мати, брати i сестри. У п’ять років Маруся вже підспівувала дорослим, а в семирічному віці дівчинка свої перші вокальні навики здобувала у церковному хорі Києво-Печерського собору. Тут вона знайомиться 3 нотною грамотою, з виконавською дисципліною і розвиває музичну пам'ять. У своїх спогадах вона писала: “...Взагалі навчанню дітей співу, звичайно, лише під керівництвом досвідченого й чуйного педагога, я надаю дуже великого значення. Крім того, що заняття співом у ранньому віці надзвичайно розвивають слух, музикальність і пам'ять, вони сприяють також здоровому фізичному розвитку дітей” [7, 10]. У 1901 році Марія стала ученицею приходського училища при київському “Арсеналі”, яке закінчила 1906 року.
Якось у Печерському соборі ïi почув баритон М. Бочаров і переконав регента показати дівчину педагогові-вокалісту. Педагог училища М. АлексєєваЮневич сказала їй, що “голос $є$ і красивий, та для сцени він повинен бути, як бомба", і порекомендувала їй прийти через два роки. Весь свій вільний час талановита дівчина самотужки вивчала складний вокальний репертуар. I вже через рік знову прийшла до педагога, а за два місяці напруженої праці успішно склала вступний іспит. У 1908 році була зарахована до класу професора Алексєєвої-Юневич, але наука давалася важко через відсутність вдома фортепіано, тяжку хворобу батька, нестачу коштів для оплати за навчання. Завдяки наполегливості професора О. Виноградського, дирекція згодом звільнила Марію від оплати. За час навчання вона познайомилася 3 творчістю таких видатних акторів, як М. Заньковецька, О. Мишуга, Л. Собінов, Ф. Литвин, М. Фігнер, І. Єршов та ін., які в цей час виступали на київській сцені.

На протязі усього свого творчого життя М. Литвиненко-Вольгемут з великою вдячністю згадує усі професійні настанови свого першого викладача Марії Юневич. Вона їй рекомендувала найдраматичніші оперні партії співати легким ліричним звуком, повністю голос розкривати тільки в кульмінаційних моментах. Постійно звертати увагу на виробленні міцного дихання, що дає тверду опору звукові. "Мене вчили співати м'яким, рівним в усіх регістрах звуком, добиваючись чистоти інтонації, вокальної гнучкості, тобто уміння відтворювати голосом зміни і найтонші відтінки людських почугтів" [7, 14].

Після успішного закінчення музичного училища, володарка лірико-драматичного сопрано Марія Литвиненко отримує цілий ряд запрошень i, навіть, до Москви. Проте, за рекомендацією диригента О. Кошиця вступає до театру Миколи Садовського. Це була іiі давня мрія. Дебютувала Марія партією Наталки в опері М. Лисенка “Наталка-Полтавка". Ї̈і виступ був особливо успішним, і розчулив самого М. Лисенка, який після першої дії прийшов за куліси, щоб привітати виконавицю. Критики оцінили їі сценічне обдарування, відзначаючи вплив виконавської манери М. Заньковецької. Робота у театрі М. Садовського для талановитої вокалісти була справжньою школою акторської майстерності. Вона усвідомила, що головне - це розкриття характеру, думок та почуттів героя. На все життя вона запам'ятала основні вимоги вчителя: “Дай душу, людську душу розкрий”. Водночас усі партії М. Литвиненко відпрацьовувала з М. Юневич, а сценічний бік ролі вдавався їй важко. Вона про це 


\section{МИСТЕЦЬКАДІЯЛЬНІСТЬМАРІЇЛИТВИНЕНКО-ВОЛЬГЕМУТ В КОНТЕКСТІ РОЗВИТКУ УКРАЇНСЬКОӤ МУЗИЧНОЇ КУЛЬТУРИ}

відверто говорила режисерові, а він відповідав: “Оце й добре, що не вмієш. Роби те, що підкаже тобі серце, почуття, і все буде гаразд” [7, 19].

В театрі М. Садовського вона виконала партію Катерини 3 однойменної опери М. Аркаса, Панночки 3 опери “Утоплена" М. Лисенка, Оксани 3 “Різдв'яної ночі” М. Лисенка, Дідони 3 “Енеїди” М. Лисенка, Роксолани з опери "Бранка Роксолана" Д. Січинського, Настусі з опери "Пан Сотник" Г. Козаченка. Особливий успіх у Литвиненко був у таких драматичних партіях, як Галька з однойменної опери С. Монюшка і Сантуцци 3 “Сільської честі” П. Масканьї.

М. Литвиненко теж грала у драматичних спектаклях та опереткових виставах театру. Це зокрема Панночка у “Вії, Гала у виставі “Пісні в лицях” та Оришка у п’єсі “Пошились у дурні” М. Кропивницького, Кулина в Лисенкових “Чорноморцях”, Уляна у “Сватанні на Гончарівці” Г. Квітки-Основ”яненка, Килина у п'єсі “Про що тирса шелестіла” С. Черкасенка та Хотина у “Сорочинському ярмарку” М. Старицького. Але справжнім захопленням молодої співачки стала опера. "Уроки майстерності, які отримала виконавиця у трупі корифеїв українського театру, визначили її подальше творче життя, упродовж якого актриса реалізувала на сцені два напрямки свого таланту - вокальний і акторський. Максим Рильський зазначав, що за рівнем дикції та сценічної мови Марію Литвиненко-Вольгемут можна дорівняти лише до Бориса Гмирі та Івана Козловського“ [3].

У 1914 році іiі спів почув провідний тенор відомого Петроградського театру музичної драми В. Севастьянов. Він був вражений чарівним голосом та переконливою грою української співачки і офіційно запросив іiі до Петрограда. Після довгих роздумів Марія погодилась на пропозицію В. Севастьянова, але не наважувалась про це сказати М. Садовському. Зрештою він сам здогадався і сказав їй: “Їдь, мала. Тобі вже треба більшого простору, а цього ми зараз дати не можемо. Зростай, вдосконалюйся і не забувай рідної сторони. Буде колись і на Україні велика оперна сцена" [7, 24].

Роки роботи української співачки в Петрограді були надзвичайно успішними. Під керівництвом режисера Й. Лапицького і таких відомих на той час диригентів, як М. Біхтер, О. Павлов-Арбенін, А. Маргулян співачка формувала відчуття глибокого акторського перевтілення в образ простоти і щирості сценічної поведінки, особливу увагу надаючи чіткій дикції і виразному інтонуванню слова. Дебютувала Марія в опері "Снігуронька" М. Римського-Корсакова. Образ
Купави був їй дуже близьким, бо нагадував ій дівчат-українок, яких грала на сцені театру М. Садовського. У цій партії слухав українську співачку великий Федір Шаляпін і був зачарований іiі співом.

Співачка старанно працювала над створенням вокально-сценічних образів у операх П. Чайковського (партія Лізи в “Піковій дамі”, Оскани в “Черевичках", Тетяни в “Свгенії Онєгіні” та Насті в “Чародійці”). Потім була робота над складною партією Анни в опері О. Даргомижського “Кам'яний гість”. Крім цього виконавиця співала провідні партії західноєвропейської оперної класики. Це Аїда в однойменній опері Д. Верді, Мікаєла в “Кармен” Ж. Бізе, Маргарита в “Фаусті” Ш. Гуно, Джульєтта в “Казках Гофмана" Ж. Оффенбаха та Кундрі в опері “Персифаль” Р. Вагнера. Кропітка і наполеглива праця приносила їй жаданий успіх.

Весною 1916 року М. Литвиненко-Вольгемут повернулася в Україну, незважаючи на всі переконання і запрошення інших столичних театрів. "Україна повинна і буде мати свій великий музичний театр - і кому як не мені в моєму теперішньому положенні активно сприяти цьому” [2, 14].

Іїі дебют на київській сцені відбувся восени в партії Лізи в “Піковій дамі” і став справжнім святом для всіх шанувальників оперного мистецтва. Але всі надії на створення національного оперного театру були марними. Не було поставлено жодної української вистави. Тоді Київська опера була звичайним провінційним театром. Протягом одного сезону співачка підготувала партію Тоски в однойменній опері Д. Пуччіні, Надію в “Аскољдовій могилі” О. Верстовського та Ярослану в “Князі Ггорі”, О. Бородіна. Виконання цих партій принесло їй великий успіх. Одночасно Марія брала активну участь у рідному театрі М. Садовського, виступала з українським репертуаром в концертах, їздила на гастролі, де співала уривки із “Запорожця за Дунаєм”.

У 1919 році збулася заповітна мрія М. ЛитвиненкоВольгемуг - була створена Українська державна музична драма, фундаторами якої стали М. ЛитвиненкоВольгемут, видатний режисер та мистецький керівник “Молодого театру” Лесь Курбас, талановитий художник-декоратор Анатолій Петлицький, композитор Яків Степовий і диригент Михайло Багриновський.

28 липня 1919 року відбулася прем'єра Української музичної драми постановкою опери “Утоплена" М. Лисенка. І це було знаменним, бо саме М. Лисенко створював грунт для такого театру. М. Литвиненко-Вольгемут виконувала 


\section{МИСТЕЦЬКАДІЯЛЬНІСТЬ МАРІЇЛИТВИНЕНКО-ВОЛЬГЕМУТ В КОНТЕКСТІ РОЗВИТКУ УКРАЇНСЬКОӤ МУЗИЧНОӤ КУЛЬТУРИ}

партію Утопленої. Критика зазначала: “Ії̈ образ Утопленої просякнений місячним світлом, холодом стоячих вод, поезією русалчиного царства. Він хвилював, зворушував та прегарно доповнювався звучним, чистим, як джерельна вода, голосом русалки" [7, 43 - 44].

Наступною роботою співачки була партія Гальки в однойменній опері С. Монюшка (українською мовою), яку вона готувала 3 диригентом П. Гончаровим та режисером Л. Курбасом, який захоплювався творчістю співачки і працював 3 нею в поза репетиційний час. Та у зв’язку з важкою політичною ситуацією в цей період постановка "Гальки“" не відбулася і перший український оперний театр припинив свою творчу діяльність.

У 1920 році М. Литвиненко-Вольгемут разом зі своїм чоловіком Г. Вольгемутом, відомим театральним адміністратором, виїхала до Вінниці, де вони організували український музичнодраматичний театр. Крім драматичних спектаклів ставили й оперні - “Галька" С. Монюшка, “Сільська честь” П. Масканьї, “Запорожець за Дунаєм” С. Гулака-Артемовського, "Утоплена", "Енеїда" та "Різдв’яна ніч” М. Лисенка, "Русалка" О. Даргомижського та "Рогнеда" О. Серова. Напружену роботу в театрі, чисельні концерти, велику громадську діяльність мисткиня поєднувала 3 педагогічною працею, викладаючи у Вінницькій народній консерваторії.

“3 15 липня до 15 серпня 1922 року у Вінниці гастролював Київський театр опери та балету. Для участі в його спектаклях була запрошена М. Литвиненко-Вольгемут. 3 великим успіхом виступала вона в “Піковій дамі”, “Аїді” та інших операх. На запрошення колективу театру вона ввійшла в його склад і виїхала в Київ" [7, 48]. У Києві вона успішно співає головні партії в “Аїді”, “Піковій дамі”, “Князі Ігорі”, “Казці про царя Салтана”, “Жидівці”, “Тосці” Дж. Пуччіні. Але найбільшим досягненням у цьому сезоні були головні партії в таких музичних драмах Р. Вагнера як “Тангейзе”, “Лоенгрін” та “Валькірія". Вагнерівські опери ставили перед співачкою багато цікавих вокальних і акторських завдань, які вона блискуче розв'язала. Режисура в цей період в театрі була найслабшим місцем, але досвідчена співачка й акторка сама знаходила правдиві і переконливі тлумачення вокальносценічних образів вагнерівських героїнь.

М. Литвиненко-Вольгемут була ініціатором здійснення оперних спектаклів на Київській сцені українською мовою. Керівництво театру всіляко цьому перешкоджало, але наполегливість і твердість артистів і Марії Вольгемут, підтриманих громадськістю примусили показати дві вистави українською мовою, це "Галька" та “Сільська честь”. На жаль постановка цих спектаклів не стала подією. Відсутність в театрі режисури хвилювала співачку і вона все більше думала про зміну театру. Її теж обурювало ставлення Київської дирекції до недостатності постановок українських оперних спектаклів. У 1923 році М. Литвиненко-Вольгемут переїжджає на роботу до Харківського театру опери та балету, але 3 умовою, що половину свого репертуару співатиме українською мовою. 31 січня 1924 року відбулася у Харкові прем'єра “Гальки” і бенефіс М. Литвиненко-Вольгемут. Це було знаменною подією і величезним успіхом. “Браво! I навіть бравісімо! - писав після вистави вражений Остап Вишня. - Бенефіціантка Гальку співала... і грала. I як співала! I як грала! Такі закінчені і сценічно, і вокально образи рідко коли доводиться бачити та чути. Голос! Він так звучав, він так дзвенів! Скільки було чарівної сили, скільки краси!" $[7,57]$.

Зі спогадів знаменитого Івана Козловського, який тоді співав партію Йонтека довідуємося, що “...вистава була надзвичайно хвилюючою. Вокальний образ Гальки у виконанні Марії Іванівни, вражав, чарував, захоплював рідкісною поетичністю" [7, 58].

М. Литвиненко-Вольгемут, як одна 3 найактивніших ініціаторів створення української опери у Харкові, гаряче пропагувала національну оперну музику і рідну мову. Ї̈і активна творча діяльність, пропаганда української оперної музики, великий успіх постановок на сцені Харківського театру “Катерини”, “Тараса Бульби”, “Гальки" сприяли організації і створенню в столиці України національного оперного театру. Від 3 жовтня 1925 року в Харкові було урочисто відкрито Український державний театр опери та балету. Першою виставою нового театру був комедійний “Сорочинський ярмарок” М. Мусорського. 3 особливим задоволенням працювала співачка над партією Марти в опері Альбера “Долина”, постановку якої здійснював Й. Лапицький. Співачка вважала, що досвідчений і талановитий режисер-реаліст сприятиме успішному розвиткові молодого українського оперного театру. І вона не помилилася, вже перша постановка стала значною подією у творчому житті столичного колективу. Подальші досягнення видатної української співачки були пов'язані з режисурою Й. Лапицького. Вона створила образ Мікаели в "Кармен” Ж. Бізе, Джульєтти в “Казках Гофмана" Ж. Оффенбаха та Купави в “Снігуроньці” М. Римського-Корсакова.

“Кожна вистава 3 участю чудової співачки 


\section{МИСТЕЦЬКАДІЯЛЬНІСТЬ МАРІЇЛИТВИНЕНКО-ВОЛЬГЕМУТ В КОНТЕКСТІ РОЗВИТКУ УКРАЇНСЬКОӤ МУЗИЧНОӤ КУЛЬТУРИ}

змінювала авторитет молодої української опери, ставала справжньою подією в мистецькому житті Харкова" [7, 66]. Власне на сцені народного театру вона зіграла Одарку в “Запорожці за Дунаєм” якупідготувалаз великим П. Саксаганським, котрий близкуче зіграв Івана Карася. 3 цією партією співачка не розлучалася усе своє творче життя.

2 липня 1926 року М. Литвиненко-Вольгемут отримала звання заслуженої артистки України. Ї̈̈ мистецька діяльність була широкою i багатогранною і вона успішно брала участь у виставах Українського державного народного театру, директором якого був Г. Вольгемут.

Співачка активно працює над створенням нових сценічних образів, оволодіваючи різними композиторськими стилями під керівництвом таких видатних диригентів, як А. Пазовський, А. Маргулян, В. Тольба і М. Покровський. Вона досконало вивчає партитури Д. Россіні і Д. Верді, Д. Пуччіні і Д. Мейєрбера, О. Даргомижського і М. Римського-Корсакова. Переважну більшість партій з опер цих композиторів вона перша співає українською мовою. Співачка активно працює в тісній співдружності 3 українськими композиторами. Зокрема, Б. Лятошинський, В. Косенко та О. Чишко головні жіночі партії пишуть, враховуючи яскраву виконавську індивідуальність М. Литвиненко-Вольгемут.

М. Литвиненко-Вольгемут була тим центром, навколо якого завжди кипіла напружена і творча робота. До їі порад прислухалися відомі співаки, постійно консультувалися диригенти і керівництво театру. Вона часто виїжджала на гастролі до Києва та Одеси, співала у виставах новостворених українських оперних театрів Дніпропетровська та Вінниці. Велика творча дружба довгий час пов'язувала мисткиню 3 видатним співаком I. Паторжинським. "Ми дуже часто були постійними партнерами у творах української оперної класики та в інших виставах нашого театру, - писала співачка, - були першими виконавцями багатьох партій російських опер на українській сцені. Сформувався і наш спільний репертуар, з яким ми систематично виступали в концертах..." [7, 77].

У 1935 році, рік після перенесення столиці України до Києва, Литвиненко-Вольгемут разом 3 Паторжинським та іншими видатними українськими співаками переїжджають до столичного театру опери та балету. 1936 року співачці присвоєно почесне звання народної артистки СРСР. Ця нагорода була радісно сприйнята усіма майстрами українського оперного театру, як визнання творчих досягнень усього національного музично-театрального мистецтва.
Новим творчим досягненням співачки на столичній сцені була партія Насті в опері "Тарас Бульба” М. Лисенка, яка для неї найулюбленішою і найдорожчою. У ній звучала тема самовідданого героїзму жінки-матері. Цю тему вона пронесла через всю свою подальшу творчу діяльність.

На весні 1940 року Київський театр опери та балету імені Т. Шевченка гастролював у Львові. Першим спектаклем була "Пікова дама" П. Чайковсього блискуче поставлена М. Смоличем з Литвиненко-Вольгемут в партії Лізи. Львівський рецензент К. Дніпров писав: “...Гнучкий, мелодичний, чудового тембру голос іiї завжди чарує глядача. Всю партію Лізи, особливо тужливу арію “Від чого плачуть очі” вона виконувала 3 властивою їй простотою і неповторною щирістю. Чудесне творіння Чайковського - партія Лізи знайшла свого достойного, прекрасного виконавця" $[7,86]$.

Веніамін Тольба у своїх спогадах писав: “...Більше в моєму житті, здається, не було такого потрясіння від вистави i, головне, від одного домінуючого образу Лізи - Литвиненко... Так, якщо хто і заслужив епітет “український соловейко" чи “перлина української оперної сцени”, які стали тепер трафаретом від надмірного вживання, то це в першу чергу M.I. Литвиненко-Вольгемут, і поряд з іiі іменем ці епітети ніби оживають” $[6,301]$.

У червні 1941 року театр закінчив черговий сезон, а підготовку до гастролей перервав початок війни. М. Литвиненко-Вольгемут разом 3 колективом театру виїжджають до Уфи, а потім до Іркутська, підпорядковуючи свою діяльність вимогам воєнного часу. Її схвильований спів: “Україно, рідний краю, серцем я тебе бажаю!”сприймався як патріотичний заклик. М. Рильський писав: “... взимку цього року, коли Київський оперний театр поставив в Уфі “Запорожця за Дунаєм”, наша артистка показала нам щось нове: в останній дії, звертаючись до рідних ланів, за якими знудьгувалася душа, Литвиненко - Одарка ударила по таких високих, таких вражаючих струнах, що всі глядачі плакали, не соромлячись своїх сліз, тому, що це були сльози любові до своєї Вітчизни та віри в неї” $[7,88]$.

В Іркутську київський оперний колектив не забув своїх кращих традицій, усі активно працювали над постановкою нової української опери М. Вериківського "Наймичка" за однойменною поемою Т. Шевченка (лібрето К. Литвиненка). Головну партію наймички Ганни співала М. Литвиненко-Вольгемут. Прем'єра відбулася 13 листопада 1943 року і стала справжнім тріумфом видатної української 


\section{МИСТЕЦЬКАДІЯЛЬНІСТЬ МАРІЇЛИТВИНЕНКО-ВОЛЬГЕМУТ В КОНТЕКСТІ РОЗВИТКУ УКРАЇНСЬКОӤ МУЗИЧНОӦ КУЛЬТУРИ}

співачки. У 1945 році, після повернення театру до Києва, колектив відновив свої кращі довоєнні постановки. В цей період почалася підготовка до 50-річного ювілею М. Литвиненко-Вольгемут. У Колонному залі ім. М. Лисенка була організована зустріч зі столичною інтелігенцією, під час якої М. Рильський, закінчуючи свій виступ, сказав: “Солов'я української опери М. ЛитвиненкоВольгемут знають і люблять скрізь на Україні, за їі межами. Але солов’ї співають тільки весною. Марія Іванівна ввійшла у своє творче літо, а голос iii лунає так само повнозвучно і чудесно. Побажаємо ж їй, щоб довгі-довгі роки цвіло й було iï літо, щоб прекрасний дар іiї довго ще чарував, благородив і окриляв людські серця" [7, 103].

У 1946 році співачка удостоєна високого звання Лауреата Державної премії першого ступеня. Проте нагороди та визнання ії творчих досягнень ніколи не заспокоювали співачку, вона постійно прагнула, до створення нових вокально-сценічних образів, яким став глибокий національний образ Варвари в опері К. Данькевича “Богдан Хмельницький”. Цю партію композитор писав спеціально для відомої виконавиці.

Концертний репертуар М. ЛитвиненкоВольгемут був великим i різноманітним. Знаменита оперна співачка була ще й прекрасною камерною виконавицею, тонким інтерпретатором творів майже усіх композиторських шкіл і напрямів світової вокальної музики. Більшість 3 них вона співала по декілька сезонів, інші співала все своє життя, постійно вдосконалюючи їх. “Я ніколи не обмежувалась якимось певним здобутком в тій чи іншій партії, - писала співачка. - Свої творчі шукання я не припиняла навіть після багаторазових виступів у якійсь партії. Праця актора, як і вся інша, повинна являти собою постійний, невпинний рух вперед” [7, 138]. Опановуючи кожну партію, співачка напам'ять знала партії інших персонажів і навіть оркестрову партитуру. В такий спосіб вона почувала себе на сцені вільно і невимушено, вся увага була зосереджена на створенні образу героїні. У своїх спогадах Ніна Скоробагатько зазначала: "Перед виступом Марія Іванівна ніколи не розспівувалася i нічого не повторювала. Проте, коли починала співати, завжди була у повній формі. Голос їі, наче точний інструмент, зберігав одинаково високу позицію, інтонаційну чистоту, теплоту і свіжість звучання" [5, 309].

Поряд 3 відомими оперними аріями, вона виконувала кращі зразки західноєвропейської і російської вокальної лірики. Це, зокрема, твори Ф. Шуберта, Р. Шумана, Е. Гріга, Й. Брамса, романси М. Глінки, О. Даргомижського,
П. Чайковського, М. Римського-Корсакова, С. Танєєва, С. Рахманінова, Ц. Кюї. Особливе місце у їі виступах займали пісні та романси українських композиторів-класиків М. Лисенка, Я. Степового, К. Стеценка, М. Леонтовича та ін.

Почесне місце у концертному репертуарі (понад 300 пісень!) займала українська народна пісня, любов до якої вона увібрала $з$ дитинства. Співачка віддавала перевагу пісням про жіночу долю. У виконання фольклорних зразків вона вкладала всю свою душу, майстерність, безпосередність і неповторність емоційних почуттів. "Її виконання визначалося стриманою манерою, без будь-якої екзальтації чи сентиментальності" [7, 150].

Найбільш виконувані пісні: про трагічну долю та нещасне кохання - “Чого вода каламутна", "Не питай, чого в мене заплакані очі”, “Ой Боже ж мій, Боже, милий покидає”, "Нащо мені чорні брови”, “Чи я в лузі не калина була”, “Ой сама ж я сама”, “Ой і зрада, карі очі, зрада”, “Ой як би я горе знала”, “Шумить, гуде дібровонька”, “Де ти бродиш моя доле”, “Голівонько моя бідная”; пісні лагідні, ніжні, ліричні та грайливі - “Ой за гаєм, гаєм”, “Чом, чом не прийшов”, ”Ой піду я до млина”, “Сусідка”, “На вулиці скрипка грає” та ін.

3 особливою увагу мисткиня надавала обробкам українських народних пісень, здійснених Л. Ревуцьким, М. Лисенком, Б. Лятошинським, П. Сокальським, К. Стеценком, А. Штогаренком, Я. Степовим, М. Леонтовичем, О. Чишком, Ю. Мейтусом, В. Косенком, Н. Сдлічкою та інші. Проникливо співачка виконувала романси М. Лисенка. Охоче включала до свого репертуару твори на слова Т. Шевченка “Ой пішла я у яр за водою”, “Садок вишневий коло хати”, "У перетику ходила”, “Хустиночка”, “Ой одна я одна”. Виразними вокально-тембровими фарбами співачка передавала образний зміст і настрої національної романсової лірики. Це особливо стосується творів Я. Степового "Розвійтеся 3 вітром” на сл. І. Франка, "Утоптала стежечку" на сл. Т. Шевченка, “Зимою” на сл. О. Олеся та інші.

Чимало пісень-дуетів (“Куди їдеш, Явтуше?”, “Скажи мені правду”, “Дівчино, кохана”, “Здорова була”) було в репертуарі виконавиці, які вона співалазі своїм постійним партнером I. Паторжинським. Туг вони виявляють не тільки вокальну, а й блискучу акторську майстерність. Співаючи в дуеті, ці видатні майстри розкривали перед слухачами “внутрішнє життя пісні” (Ф. Шаляпін) і і1і неповторний зміст.

Навесні 1953 року Марія ЛитвиненкоВольгемут востаннє вийшла на рідну київську 


\section{МИСТЕЦЬКАДІЯЛЬНІСТЬ МАРІЇЛИТВИНЕНКО-ВОЛЬГЕМУТ В КОНТЕКСТІ РОЗВИТКУ УКРАЇНСЬКОӤ МУЗИЧНОӤ КУЛЬТУРИ}

оперну сцену з партією Одарки в “Запорожці за Дунаєм”. Символічно, що цією оперою в партії Оксани початкуюча співачка починала свій творчий шлях на професійній сцені, а завершила свою тривалу і плідну сценічну долю літньою і огрядною Одаркою. У тому ж 1953 році М. Литвиненко-Вольгемуг разом 3 I. Паторжинським знялися у повнометражному фільмі-опері “Запорожець за Дунаєм”, створеномуна Київській кіностудії імені О. Довженка. Це була перша кольоровакіноопера, хочв 1936роцірежисерI.Кавалерідзе екранізував “Наталку Полтавку”, де співачка озвучила партію Наталки.

Незважаючи на те, що в період зйомок “Запорожця за Дунаєм” співачка вже була тяжко хвора, для всіх учасників стала прикладом творчої самовідданості, дисциплінованості і надзвичайної скромності. Фільм мав величезний успіх, це був тріумф яскравого мистецтва українських корифеїв і насамперед вокально-акторського мистецтва М. Литвиненко-Вольгемут. 3 квітня 1966 року М. Литвиненко-Вольгемут завершився життєвий шлях видатної співачки.

Понад тридцять років М. ЛитвиненкоВольгемут віддала педагогічній роботі у столичній консерваторії. Передаючи власний досвід та свої мистецькі принципи студентам, вона кожного разупереосмислювала свій творчий шлях і ті принципи, які були знайдені інтуїтивно, вибудовувалися в систему певних методичних правил, набували певних теоретичних узагальнень. Серед учнів співачки - відомі виконавці і педагоги: Дмитро Мухарський, Володимир Гуров, Ніна Клименко, Марина Шевчук, Олександра Шестакова і Зінаїда Бузина [8].

Вона була однією із небагатьох оперних співаків, яка до останніх років зберегла красу, свіжість і чарівність голосу, бездоганну інтонацію та прекрасне володіння звуком. Все це свідчило про правильну постановку і вірне використання голосу протягом сорокарічного творчого шляху.

Де б вона не співала, ніколи не розлучалася 3 чарівною, задушевною піснею рідного народу, 3 близькими серцю образами жінок-українок героїнями національних оперних творів. "Коли я сьогодні згадую про видатну українську співачкуактрису, мимоволі з'являється думка: скільки повчального, вартого наслідування, корисного для сучасної оперної молоді було в її творчому житті! Та головне, мабуть, це - самовіддане, щире служіння рідному мистецтву, постійна вимогливість до себе й щоденна напружена праця" [1, 315], згадував М. Гришко.

Висновки. М. Литвиненко-Вольгемут - співачка світового класу i, разом з тим, глибоко народна, українська національна співачка. Вона співала не лише голосом, але головою й серцем. Ïї голос був повного діапазону від меццосопранових грудних нот до граничних верхів, рівний по всьому діапазоні, високопозиційний, добре прикритий, але разом $з$ цим світлий і летючий. Це був звук 3 дивовижно чистою інтонацією, з виразною і природною дикцією, в якому музика і слово зливалися в одне ціле.

Будучи на педагогічній праці вона постійно вдосконалювала прийоми викладання, щораз шукала нових методичних засобів. Вокальновиконавські традиції видатної української співачки і сьогодні живуть у творчості талановитих майстрів оперного мистецтва. Її творчість завжди буде невичерпним джерелом натхнення для подальших поколінь.

\section{ЛІТЕРАТУРА}

1. Гришко М. Зірка української опери. Українські співаки у спогадах сучасників / Авторупор. І. Лисенко. Київ, 2003. С. 315.

2. Ісаченко І. Марія Іванівна ЛитвиненкоВольгемут. Київ, 1960. С. 14.

3. Кроп Т. Ї̈̈ спів i досі заворожує. Літературна Україна. 2012. № 17.

4. Рудницький А. Українська музика: історично-критичний огляд. Мюнхен, 1963.С. 271.

5. Скоробагатько Н. Музикальна співачка. Українські співаки у спогадах сучасників / Авторупор. І. Лисенко. Київ, 2003. С. 309.

6. Тольба В. Велика співачка.Українські співаки у спогадах сучасників / Автор-упор. І. Лисенко. Київ, 2003. С. 302.

7. Швачко Т. Марія Литвиненко-Вольгемут. Київ, 1972.183 с.

8. 125 років від дня народження Марії Іванівни Литвиненко-Вольгемут. URL: http://biog.in.ua/125rokiv-vid-dnya-narodjennya-mariyi-ivanivnilitvinenko-vole.html

\section{REFERENCES}

1. Hryshko, M. (2003). Zirka ukrainskoi opery [The star of the Ukrainian Opera]. Ukrainian singers in the memoirs of the contemporaries. Author-focused. I. Lysenko. Kyiv, p. 315. [in Ukrainian].

2. Isachenko, I. (1960). Mariia Ivanivna Lytvynenko-Volhemut [Mariya LytvynenkoVolgemut]. Kyiv, p. 14. [in Ukrainian].

3. Krop, T. (2012). Yii spiv i dosi zavorozhuie [Her singing is still mesmerizing]. Literary Ukraine, Vol. 17. [in Ukrainian].

4. Rudnytskyi, A. (1963). Ukrainska muzyka: 


\section{ПЕДАГОГИ ТАНАТХНЕННИКИ ОСНОВОПОЛОЖНИКАУКРАЇНСЬКОЇ ЕСТРАДИ, ПОЕТАІКОМПОЗИТОРАВОЛОДИМИРАІВАСЮКА}

istorychno-krytychnyi ohliad [Ukrainian music: a historical and critical review]. Mynkhen, p. 271. [in Ukrainian].

5. Skorobahatko, N. (2003). Muzykalna spivachka [Music singer]. Ukrainian singers in the memoirs of the contemporaries. Author-focused. I. Lysenko. Kyiv, p. 309. [in Ukrainian].

6. Tolba, V. (2003). Velyka spivachka [Great singer]. Ukrainian singers in the memoirs of the contemporaries. Author-focused. I. Lysenko. Kyiv, p. 302. [in Ukrainian].

7. Shvachko, T. (1972). Mariia Lytvynenko-Volhemut [Mariya Lytvynenko-Volgemut]. Kyiv, 186 p. [in Ukrainian].

8.125 rokiv vid dnia narodzhennia Marii Ivanivny Lytvynenko-Volhemut [125 years from the day of birth of Maria Ivanovna Lytvynenko-Volgemut]. Available at: http://biog.in.ua/125-rokiv-vid-dnya-narodjennyamariyi-ivanivni-litvinenko-vole.html [in Ukrainian].

Стаття надійшла до редакції 22.04.2019

УДК 78.071.4(477):78.071.2(477.83)

DOI:

Лілія Кобільник, старший викладач кафедри методики музичного виховання і диригування Інституту музичного мистецтва Дрогобииького державного педагогічного університету імені Івана Франка

\section{ПЕДАГОГИ ТА НАТХНЕННИКИ ОСНОВОПОЛОЖНИКА УКРАЇНСЬКОЇ ЕСТРАДИ, ПОЕТА І КОМПОЗИТОРА ВОЛОДИМИРА ІВАСЮКА}

У статті досліджуються впливи на творчість основоположника української естради Володимира Івасюка педагогів, поетів, композиторів, діячів культури і мистецтва, української народної творчості, енергетики Украӥнських Карпат.

1971 рік-початок творчої співпрачі В. Івасюка з майбутніми корифеями украӥнської естради Софією Ротару, Василем Зінкевичем та Назарієм Яремчуком. 31972 року почалася творча співпраия В. Івасюка 3 львівськими поетами Ростиславом Братунем, Богданом Стельмахом, Романом Кудликом, Миколою Петренком. В. Івасюк очолював Клуб творчої молоді у Львові з досить широким спектром діяльності, яка стимулювала його до популяризачії авторських творів та народжувала задуми нових пісень.

Ключові слова: талант; натхненники; усна народна творчість; пісенна творчість; камерноінструментальні та фортепіанні твори; естрадні пісні; ансамблі; співпраия; енергетика Українських Карпат.

Jim. 9.

Liliya Kobilnyk, Senior Lecturer of the Music Education and Conducting Department of the Institute of Musical Art Drohobych Ivan Franko State Pedagogical University

\section{EDUCATORS AND MASTERMINDS OF THE FOUNDER OF UKRAINIAN POP MUSIC, POET AND COMPOSER, VOLODYMYR IVASYUK}

The phenomenon of creativity of the poet and composer, Volodymyr Ivasyuk, is not fully disclosed yet. One of the reasons for this is that after the death of the artist in 1979, his name was spoken in whispers for a long time and the meaning of his work was keeping silent. However, songs of the composer broke the wall of silence and flooded the whole world.

This article examines the influence of teachers, poets, composers, cultural and art figures, Ukrainian folk art, and the energy of the Ukrainian Carpathians on Volodymyr Ivasyuk, who is the founder of the Ukrainian variety.

Highly educated parents of Volodymyr instilled his high moral qualities, love to all beautiful, and strong patriotism. A teacher of the Kitsman Music School Yuriy Vysnyuk included works of such composers as Beethoven, Mozart, Schubert, Tchaikovsky, and Lysenko to the Volodymyr's repertoire. Yuriy Vysnyuk claims in his memoirs that Volodymyr Ivasyuk was in love with Ukrainian folk songs. The talent of V.Ivasyuk was polished in such artistic collectives of the Chernivtsi Medical Institute as the Song and Dance Ensemble "Trembita" (head Volodymyr Kryyak) and VIA "Carpathians" (directed by Valery Gromtsev). Volodymyr brought his songs "Chervona Ruta" and "Vodogray" exactly to Valery Gromtsev.

The Ukrainian folk art was the inspiration for the talented artist. Volodymyr participated in folk expeditions of his father, recorded old songs and ballads, and was fond of the beauty of the Ukrainian Carpathians. Volodymyr was creating his various landscapes and portraits under the impression of the beauty of the Carpathians.

1971 was the beginning of the creative collaboration with the future luminaries of the Ukrainian variety Sofiya Rotaru, Vasyl Zinkevich and Nazariy Yaremchuk. Professor Leszek Mazepa gave adequate knowledge and creative skills to Volodymyr during his studying at the Lviv National Academy of Arts named after M. Lysenko. Since 